Views \& Reviews Personal View

\title{
If the pope can change his mind on condoms, why not emergency contraceptives?
}

BMJ 2010; 341 doi: http://dx.doi.org/10.1136/bmj.c7073 (Published 21 December 2010) Cite this as: BMJ 2010;341:c7073

\section{Sara Carrillo de Albornoz, MSc student in public health, London School of Hygiene and Tropical Medicine \\ carrillo.sara@gmail.com}

In November Pope Benedict XVI declared the use of condoms acceptable in certain cases.1 In comments quoted in the Vatican newspaper L'Osservatore Romano he said, "There can be single cases of justified use of condoms - for example, when a prostitute uses a condom-and this can be the first step towards moralisation, the first act of responsibility to develop awareness that not everything is allowed and that we cannot do everything we want. However, this is not the true and appropriate way to fight HIV infection."

This is hardly a revolutionary stand on the use of contraceptives and on the fight against HIV, as Vatican spokesmen have hurriedly assured us, but we can only hope that it opens the way to wider discussion, adjustment of the Catholic church to the 21 st century, and a change of stance on birth control. The time has come for the church to learn from science and take a step forward in improving women's lives. Women should have information and access to a range of contraceptive methods, including the emergency contraceptive, the "morning after pill" (also known as Plan B).

Susana Chavez, director of the Peruvian sexual and reproductive rights organisation Promsex, said, "In Latin America strategies against contraceptive methods make use of the tribunals [the highest courts], taking advantage of the judges' misinformation and restrictive norms stemming from Catholic principles. The tight relationship between state and church and disregard for scientific evidence have led to a constitutional ban on emergency contraception."

Since its launch use of the emergency contraceptive has been strongly opposed by the Catholic church. In a 2000 statement the Vatican declared levonorgestrel to be an abortifacient and urged Catholics who work in the health sector "to make a firm objection of moral conscience."2

Pressure from conservatives and religious organisations has successively changed public health policies in Latin American countries, resulting in bans on the morning after pill. The constitutional courts of Ecuador, Chile, Honduras, and Peru have banned the distribution of the pill in the public sector health service, despite the opposition of health ministries, scientific and medical bodies, and civil society.

Misinformation has resulted in many healthcare professionals believing that levonorgestrel is an abortifacient. Scientific evidence has been repeatedly ignored, and the opinions of conservative groups 
and the Catholic church continue to have an enormous influence on decisions that affect sexual and reproductive health.

Levonorgestrel is the only postcoital contraceptive and is included in the World Health Organization's list of essential drugs. It is the only way for women whose contraceptive method has failed, who have experienced sexual violence, or who have simply had unprotected sex to prevent a potential pregnancy. Nevertheless use of levonorgestrel remains low because of barriers to access and lack of information. 3

WHO defines pregnancy as starting when the fertilised egg is implanted into the uterus, but many in Latin America don't accept this, instead taking the moment of fertilisation as the beginning of pregnancy. They consider any attempt to prevent implantation of the fertilised ovule to be abortion, because their constitutions recognise the right of the conceived from conception or fertilisation.

The patient information leaflet for levonorgestrel and the US Food and Drug Administration's pharmacopoeia4 indicate a potential effect of the drug on the endometrium, and conservative groups base their legal battles on these documents. However, WHO has changed its information about levonorgestrel's mechanism of action because of new scientific evidence. It states that levonorgestrel doesn't affect the implantation process: "Levonorgestrel emergency contraceptive pills (ECPs) have been shown to prevent ovulation and they did not have any detectable effect on the endometrium (uterine lining) or progesterone levels when given after ovulation. EC pills are not effective once the process of implantation has begun, and will not cause abortion." 5

After a long campaign by the Catholic church against condoms the pope has admitted that condoms may be useful to stop the spread of HIV. How long will it take him to acknowledge that the emergency contraceptive is just another method to be used in emergency situations? When will he realise that improving information about and access to levonorgestrel is one of the most cost effective strategies for avoiding unwanted pregnancies, unsafe abortions, and maternal deaths? Why does the FDA not update its information as WHO did?

In the meantime it is women who lack resources who will continue to suffer. In 200833 million (16\%) of about 208 million pregnancies worldwide resulted in unintended births and 41 million $(20 \%)$ in induced abortions. 6 In Latin America 11\% of all maternal deaths in 2003 were attributed to unsafe abortion.7

The pope's comments on condom use have made me think about the doors that could be opened. My question is: if dogma can be changed in certain cases, why not in others?

\section{Notes}

Cite this as: BMJ 2010;341:c7073

\section{References}

1. Roehr B. Pope's comment on condom use will help HIV prevention, say activists. BMJ2010;341:c6734.

2. Pontifical Academy for Life. Statement on the so-called "morning-after pill." www.vatican.va/roman curia/pontifical academies/acdlife/documents/rc pa acdlife doc 20001031 pillolagiorno-dopo en.html.

3. Schiappacasse V, Diaz S. Access to emergency contraception. Int J Gynaecol Obstet2006;94:301-9.

4. Food and Drug Administration. Prescribing information [levonorgestrel]. 
www.accessdata.fda.gov/drugsatfda docs/label/2009/021998lbl.pdf.

5. World Health Organization. Emergency contraception: fact sheet No 244. www.who.int/mediacentre/factsheets/fs244/en/index.html.

6. Guttmacher Institute. Facts on induced abortion worldwide. www.guttmacher.org/pubs/fb IAW.html.

7. World Health Organization. Unsafe abortion: global and regional estimates of the incidence of unsafe abortion and associated mortality in 2003. http://whqlibdoc.who.int/publications/2007/9789241596121 eng.pdf. 